\title{
COMPARISON OF METHODS TO DEVELOP AN IDF CURVES FOR WET ZONE IN SRI LANKA
}

\author{
Charith Wijayawardhana ${ }^{1}$ and Susantha Wanniarachchi ${ }^{1}$ \\ ${ }^{1}$ SLIIT
}

January 20, 2022

\begin{abstract}
The relationship between rainfall intensity, duration, frequency helps hydrologist to analyze the structural and hydraulic design of control structures. This relationship was determined by statistical analysis of sample records collected from different meteorological stations in Colombo district. The hydrological design was considered at different discharge rate for $2,5,10$, 25, 50 years period of time. In order to carry out this study, short durational rainfall data in wet zone were collected from Metrological Department. Three frequency analysis methods have been deployed to develop the curves. After analyzing the IDF relationship with different approaches, the best approach has chosen from the comparison. Selected best option could be used to identify IDF relationships for the areas whereas there are no rainfall data. The developed IDF curves are useful for safe design of efficient hydraulic structures and for flood management in Wet Zone.
\end{abstract}

\section{Hosted file}

Manuscript . docx available at https : //authorea.com/users/456391/articles/553452-comparison-ofmethods-to-develop-an-idf-curves-for-wet-zone-in-sri-lanka 